\title{
Information Literacy and its Application in Nursing Education
}

\author{
Dr Delwar Hossain \\ Centre for Rural and Remote Area Health, University of Southern Queensland, Australia \\ Email: delwar.hossain@usq.edu.au \\ Associate Professor Cheryl Perrin \\ Department of Nursing and Midwifery, University of Southern Queensland, Australia \\ Email: cheryl.perrin@usq.edu.au \\ Ms Kaye Cumming \\ Information Literacy and Reference Services, Library Services, Academic Services Division \\ University of Southertn Queensland, Australia \\ Email: kaye.cumming@usq.edu.au
}

\begin{abstract}
Information literacy has been embedded by the university into the first year nursing curriculum. Embedding this literacy will not necessarily ensure the nursing graduates will apply this skill to the provision of high quality evidence-based health care. For this to happen information literacy skills gained in the classroom must contribute to sound decision making based on best practice evidence. This paper discusses the findings of a three phases research project designed to (i) determine the information literacy skills, confidence and problem solving abilities of students entering the university's Bachelor of Nursing Program; (ii) determine if information literacy skills, confidence and problem solving abilities improve as a result of embedding information literacy instruction into a nursing course; and iii) ascertain whether there are any differences in information literacy skills, confidence and problem solving abilities based on the students demographic information.
\end{abstract}

Data were collected in two sequential semesters using a questionnaire administered to the students. The response rates in semester one and two were 45 and 56 per cent respectively. Student confidence and awareness regarding information literacy is positively affected by learning experiences from semester one to semester two. Students indicated that they need both specific and regular instruction to adequately retain learning. Overall the study suggests that embedding information literacy instruction into the first year, first semester nursing program is beneficial. By the second semester the information literacy confidence and awareness of students increased as a result of intracurricular instruction, however, problem solving skills need to be improved.

Index Terms - Information Literacy, Nursing, Curriculum, Problem Solving.

\section{INTRODUCTION}

Information literacy has been identified by the authors' University as an essential graduate attribute across all faculties. Through a collaborative approach involving the Library, the Learning and Teaching Support Unit, the Information Communication Technology (ICT) Division, and the Department of Nursing and Midwifery information literacy instruction has been embedded into the first year curriculum to assist nursing students acquire these skills.

The acceptance of information literacy skills as an essential attribute of undergraduates is widespread [13]. The Australian and New Zealand Institute for Information Literacy [4] defines information literacy as the "intellectual framework for recognising the need for, understanding, finding, evaluating, and using information". Jacobs, Rosenfeld and Haber [1] elaborate further and include the ability to effectively communicate research findings with awareness and an understanding of the social and ethical concerns related to the sharing of information. Being able to locate, retrieve, assess and adequately use information has always been an important part of learning, particularly in an academic setting. However in the current climate of ever-changing information technology and superfast information retrieval at our fingertips, there is an increasing awareness of the related obligations of educators [5].

Education facilities need to provide students with the necessary skills to navigate their way through information pathways, both online and otherwise. Moreover, in a nationwide review of nursing education [6] it is put forward that for future nursing professionals to be effective in "the current climate of technological change...it is crucial that they are able to maintain their competence" and "develop it through lifelong learning." To achieve this student's need the 
ability to assess and utilise the information found in a meaningful and applied manner.

While information literacy itself is a skill, it is not separate from other learning. In this way, it must be equated and applied with other instruction in order for it to be meaningful. A key finding of a New Zealand research team [7] was that embedding information literacy programs into the curriculum, rather than running them as extra- or inter-curricula, was most beneficial for nursing students. Similarly Desjardins et al.[8] found significant increases in information literacy skills for evidence-based practice one year after integrating an 'informatics for evidence-based practice' component into the nursing curriculum of first-year baccalaureate nursing courses. A United States based study of working registered nurses (RN) found that practising RN's frequently need information in their professional duties but lack the skills and confidence to utilise potential academic sources such as the Internet or bibliographic databases [9]. The literature on information literacy and the nursing profession [3] has found that integrating information literacy instruction into the nursing curricula increases students' confidence.

Low confidence levels in students have adversely affected their abilities and information seeking behaviour [10]. However, embedding these skills into the nursing curriculum will not automatically ensure that the graduates emerging provide high quality evidence-based health care. For this to occur information literacy skills gained in the learning environment must be applied to a real life situation and contribute to sound clinical decision-making based on scientifically sound best-practice evidence [11]. In a previous appraisal of an embedded information literacy program at the University of Wollongong [12], evidence was found supporting the effectiveness of this approach. Even so, uncertainty remains regarding how, and if information literacy is applied in early attempts at clinical decision-making by the students involved.

In a Welsh study [11], the retention of information technology skills as they are applied to professional nursing and midwifery were analysed. The study found a significant disparity between initial IT skills attained and later retention of these skills. It was suggested that this may be because the specific skills were not required in students' academic setting regularly enough to encourage adequate retention.

Historically nurses' clinical decision-making relied heavily on their own opinions and experience or those of professional colleagues [13]. With current emphasis on evidence-based practice and the proliferation of a new technologically enhanced information era, such dependence on potentially flawed reasoning is no longer necessary or advisable. Croke [14] expands further, adding that problem solving and associated critical thinking skills are a part of each step of the nursing process.
In an attempt to promote problem solving skills in first year nursing students, Croke [14] deconstructed the components of the decision-making process and allied each part with conceptual stages in the nursing process. Furthermore, toward the end of clinical placements, when student nurses were feeling more confident, they were increasingly able to engage in self-directed learning when faced with problem solving decisions. This would appear to bolster the presumption that if confident, students will use information literacy skills in practice.

Shorten, Wallace and Crookes [2] have identified information literacy as the crucial element toward evidence-based nursing. However, successfully embedding information literacy skills into the nursing curriculum will not automatically ensure that graduates provide high quality evidence-based health care. For this to occur information literacy skills gained in the learning environment must be applied to a real life situation and contribute to sound decision-making based on best practice evidence. Thus, information literacy provides nurses with the groundwork for a lifelong learning process. This paves the way for optimum utilisation of information literacy skills in clinical decision-making that is crucial to quality nursing care.

It is evident that information literacy is an essential skill required of nursing professionals, [3] in order to provide evidence-based health care. Therefore, this study attempts to discusses a few of the findings of a three phases research project designed to (i) determine the information literacy skills, confidence and problem solving abilities of first year nursing students entering the university; (ii) determine if information literacy skills, confidence and problem solving abilities improve as a result of embedding information literacy instruction into a nursing course; and iii) ascertain whether there were any differences in information literacy skills, confidence and problem solving abilities based on the students demographic information.

This paper is organised to explain the methodology, followed by the results and discussion of the research and conclusions.

\section{METHODOLOGY}

\section{A. Source of data}

Data were sourced for this study from X1 and X2 campus students enrolled in NURXXX, a non-clinical, compulsory first-year, first semester nursing course and NURYYYY which is the follow-on second semester nursing course which introduces clinical placement to students (Table 1). 
TABLE I. STUDENTS' ENROLMENT AND THEIR RESPONSE RATE

\begin{tabular}{|l|l|l|l|l|}
\hline Semester & \multicolumn{1}{|c|}{$\begin{array}{c}\text { Student } \\
\text { number }\end{array}$} & $\begin{array}{c}\text { X1 } \\
\text { campus }\end{array}$ & $\begin{array}{c}\text { X2 } \\
\text { campus }\end{array}$ & $\begin{array}{c}\text { Both } \\
\text { campus }\end{array}$ \\
\hline 1,2007 & $\begin{array}{l}\text { Enrolled } \\
\text { NURXXX }\end{array}$ & 229 & 67 & 296 \\
\cline { 2 - 5 } & Response & 74 & 39 & 113 \\
\cline { 2 - 5 } & $\begin{array}{l}\text { Response } \\
\text { rate }\end{array}$ & $37 \%$ & $72 \%$ & $45 \%$ \\
\hline 2,2007 & $\begin{array}{l}\text { Enrolled } \\
\text { NURYYY }\end{array}$ & 194 & 51 & 245 \\
\cline { 2 - 5 } & Response & 106 & 9 & 115 \\
\cline { 2 - 5 } & $\begin{array}{l}\text { Response } \\
\text { rate }\end{array}$ & $63 \%$ & $24 \%$ & $56 \%$ \\
\hline
\end{tabular}

\section{B. Data collection and analysis}

Both closed and open-ended questions were included in the instrument. Section A contains demographic information and section B contains statements concerning the technical skills, confidence in, and awareness of information access of the students on a 5point Likert-type scale $(5=$ strongly agree, $4=$ agree, $3=$ undecided, $2=$ disagree, and $1=$ strongly disagree). The final version of the questionnaire was revised on the basis of pilot testing, reliability, item analysis and suggestions and comments received from the project team.

A plain language statement explaining the purpose of the study, consent form, and a questionnaire was distributed to all students in semester one and two and they were encouraged to complete and return their questionnaire within a stipulated time. The overall response rates in both campuses were 45 and 56 per cent respectively (Table I).
Quantitative data were analysed using the SPSS program. Descriptive statistics such as frequency distribution, means, standard deviations and cross tabulations were used to summarize the data. T-test and analysis of variance (ANOVA) were used to determine whether there were significant differences with regard to their technical skills, confidence and awareness in information access, based on their demographic characteristics. The Tukey multiple comparison test was used to isolate the sources of significant differences [15]. Throughout the study, a .05 level of probability was used as a basis for ascertaining the significant differences in responses of the participants.

\section{Ethics approval}

Ethics approval was obtained from the University of Southern Queensland's Human Research and Ethics Committee before the study commenced.

\section{RESULTS}

\section{A. Demographic Information}

Analysis of data in Table II indicates that the majority of the students $(79 \%)$ were from the X1 campus as compared to 21 per cent from the X2 campus. The highest proportion of students $(28 \%)$ was between 16 and 18 years of age as compared to 26 per cent mature age group ( 31 years and above), 24 per cent between $22-30$ years and 22 per cent 19 and 21 years. The majority of respondents were female (88\%) and Australian (83\%) with 17 per cent from other countries.

TABLE II. DEMOGRAPHIC INFORMATION OF PARTICIPATING STUDENTS

\begin{tabular}{|c|c|c|c|c|c|c|}
\hline \multirow[t]{2}{*}{ Demographic Characteristic } & \multicolumn{2}{|c|}{ Semester 1} & \multicolumn{2}{|c|}{ Semester 2} & \multicolumn{2}{|c|}{ Combined } \\
\hline & $\mathrm{n}$ & $\%$ & $\mathrm{n}$ & $\%$ & $\mathrm{n}$ & $\%$ \\
\hline \multicolumn{7}{|l|}{ Location } \\
\hline \multirow{2}{*}{$\begin{array}{l}\text { X1campus } \\
\mathrm{X} 2 \text { campus }\end{array}$} & 74 & 66 & 106 & 92 & 180 & 79 \\
\hline & 39 & 34 & 9 & 8 & 48 & 21 \\
\hline \multicolumn{7}{|l|}{ Age } \\
\hline \multirow{4}{*}{$\begin{array}{l}16-18 \text { years } \\
19-21 \text { years } \\
\text { 22-30 years } \\
31 \text { years and above }\end{array}$} & 31 & 28 & 33 & 29 & 64 & \\
\hline & 25 & 22 & 25 & 22 & 50 & 22 \\
\hline & 26 & 23 & 27 & 24 & 53 & 24 \\
\hline & 30 & 27 & 26 & 25 & 58 & 26 \\
\hline \multicolumn{7}{|l|}{ Sex } \\
\hline \multirow{2}{*}{$\begin{array}{l}\text { Male } \\
\text { Female }\end{array}$} & 11 & 10 & 16 & 14 & 27 & 12 \\
\hline & 102 & 90 & 97 & 86 & 199 & 88 \\
\hline \multicolumn{7}{|l|}{ Country of Origin } \\
\hline \multirow{2}{*}{$\begin{array}{l}\text { Australia } \\
\text { Other countries }\end{array}$} & 93 & 82 & 96 & 84 & 189 & 83 \\
\hline & 20 & 18 & 19 & 26 & 39 & 17 \\
\hline \multicolumn{7}{|l|}{ Level of education } \\
\hline \multirow{3}{*}{$\begin{array}{l}\text { Secondary school } \\
\text { TAFE } \\
\text { University and Other } \\
\end{array}$} & 72 & 64 & 91 & 81 & 163 & 72 \\
\hline & 19 & 17 & 14 & 12 & 33 & 15 \\
\hline & 22 & 19 & 8 & 7 & 30 & 13 \\
\hline \multicolumn{7}{|l|}{ Prior enrolment to nursing } \\
\hline \multirow{3}{*}{$\begin{array}{l}\text { Attended classes on using information } \\
\text { Didn't attend classes on using information } \\
\text { Unsure }\end{array}$} & 45 & 40 & 43 & 38 & 88 & 39 \\
\hline & 57 & 51 & 54 & 48 & 111 & 49 \\
\hline & 10 & 9 & 16 & 14 & 26 & 12 \\
\hline
\end{tabular}




\begin{tabular}{|c|c|c|c|c|c|c|}
\hline \multicolumn{7}{|l|}{ At home -online computer access } \\
\hline \multirow{3}{*}{$\begin{array}{l}\text { Have online access whenever needed } \\
\text { Have online access but cannot use it often } \\
\text { Do not have online computer access }\end{array}$} & 83 & 73 & 91 & 81 & 174 & 77 \\
\hline & 11 & 10 & 9 & 8 & 20 & 9 \\
\hline & 19 & 17 & 13 & 12 & 32 & 14 \\
\hline
\end{tabular}

The highest proportion of students (72\%) stated secondary school as their entry level of education. The remainder $(28 \%)$ had attained a variety of tertiary qualifications. Almost half (49\%) of students had not participated in classes on "finding and using information" compared to 39 per cent who had participated and 12 per cent who were unsure. Over three quarters $(77 \%)$ of students had online computer access at home to use whenever needed whereas, 14 per cent had no online computer access and only 9 per cent had online computer access but could not readily use it.

\section{B. Information Literacy of Nursing Students}

Analysis of data reveals (Table III) that the students agreed that accessing information is part of their problem solving skills. Overall Students' ratings in confidence and awareness had increased between semesters one and two.

\section{Information Literacy of Nursing Students based on their semesters of study}

Table III shows that the mean ratings in problem solving skills of the students had decreased somewhat from semester one (4.14) to semester two (4.02). In contrast, the mean ratings of the students regarding their awareness of information access had insignificantly increased over the semesters. However, a statistically significant increase was found in all areas related to confidence ( $\mathrm{T}=-1.12, \alpha=.26)$ in accessing information between semester one and semester two students except for "I am able to find nursing information in another library (hospital, other university)".

\section{Information Literacy of Nursing Students based on campus location}

Students at X2 campus demonstrated slightly higher mean ratings in problem solving skills than the $\mathrm{X} 1$ campus students, as revealed in Table IV. However, the $\mathrm{X} 1$ campus students demonstrated higher mean ratings in all the confidence and awareness areas than the X2 campus students. T-test results indicate that the $\mathrm{X} 1$ campus students were significantly more confident in finding nursing information in the University Library and the Library databases, as well as finding nursing books and journals using the Library catalogue and finding nursing information using computer search engines than the $\mathrm{X} 2$ student.

TABLE III. T-TEST RESULTS OF INFORMATION LITERACY KNOWLEDGE OF FIRST YEAR NURSING STUDENTS

\begin{tabular}{|c|c|c|c|c|c|c|}
\hline \multirow{2}{*}{ Area of Information access } & \multicolumn{2}{|c|}{ Semester 1} & \multicolumn{2}{|c|}{ Semester 2} & \multirow[t]{2}{*}{ T-value } & \multirow[t]{2}{*}{ Sig } \\
\hline & Mean & SD & Mean & SD & & \\
\hline Problem solving skill & 4.14 & .54 & 4.02 & .71 & 1.47 & .14 \\
\hline $\begin{array}{l}\text { I usually try to find information as the first step in solving an } \\
\text { everyday problem }\end{array}$ & 4.04 & .65 & 3.95 & .85 & 1.03 & .30 \\
\hline $\begin{array}{l}\text { I usually try to find information as the first step in solving a } \\
\text { nursing problem }\end{array}$ & 4.26 & 63 & 4.11 & .81 & 1.48 & .14 \\
\hline Confidence in ability & 3.71 & .60 & 4.06 & .63 & $-4.23 * *$ & .001 \\
\hline I am able to find nursing information in the Uni library & 3.76 & .87 & 4.13 & .85 & $-3.24 * *$ & .001 \\
\hline $\begin{array}{l}\text { I am able to find nursing information in another library (hospital, } \\
\text { other university) }\end{array}$ & 3.48 & .84 & 3.62 & .93 & -1.12 & .26 \\
\hline $\begin{array}{l}\text { I am able to find nursing information by using the Library } \\
\text { databases }\end{array}$ & 3.76 & .84 & 4.27 & .77 & $-4.83 * *$ & .001 \\
\hline I am able to find nursing books using the Library catalogue & 3.75 & .89 & 4.04 & .92 & $-2.36^{*}$ & .01 \\
\hline I am able to find nursing journals using the Library catalogue & 3.78 & .70 & 4.16 & .83 & $-3.72 * *$ & .001 \\
\hline $\begin{array}{l}\text { I am able to locate nursing information using computer search } \\
\text { engines }\end{array}$ & 3.77 & .87 & 4.24 & .72 & $-4.46^{* *}$ & .001 \\
\hline Awareness & 4.38 & .55 & 4.46 & .53 & -1.12 & .26 \\
\hline $\begin{array}{l}\text { I am aware that any first search results may not give me the } \\
\text { information I require }\end{array}$ & 4.30 & .66 & 4.40 & 60 & -1.28 & .20 \\
\hline $\begin{array}{l}\text { I am aware that the responsibility for self-learning rests with } \\
\text { myself }\end{array}$ & 4.46 & 61 & 4.52 & .58 & -.67 & .50 \\
\hline
\end{tabular}

* Significant at $\alpha=.05$ level of probability; ** Significant at $\alpha=.001$ level of probability

\section{E. Information Literacy of Nursing Students based on their age}

Results show a significant difference between age groups in the responses made by the students in overall problem solving, encompassing significant differences in both everyday problem solving skills and nursing related problem solving skills. Tukey test revealed the mean scores on problem solving $(\mathrm{F}=3.762, \alpha=.01)$ were higher as age increased, with the greatest difference found between the 16-18 year and the 31 and above age groups. Significant differences were also 
found between age groups in information access confidence, specifically those areas related to locating information using the Library databases $(\mathrm{F}=3.762$, $\alpha=.01$ ), locating books using the Library catalogue $(\mathrm{F}=2.559, \alpha=.05)$ and locating information using computer search engines $(F=2.542, \alpha=.05)$. However, no significant differences were found in ratings on awareness statements based on their age groups.

\section{F. Information Literacy of Nursing Students based on their sex}

Data shows that females are slightly more robust in problem solving skills and confidence in their ability to access information than the male students. The female students also demonstrated significantly higher mean ratings in awareness of information than the male students $(\mathrm{T}=-2.63, \alpha=.05)$.

TABLE IV. T-TEST RESULTS OF INFORMATION LITERACY BASED ON THE CAMPUSES OF STUDY

\begin{tabular}{|c|c|c|c|c|c|}
\hline Area of Information access & Campus & Mean & SD & T-value & Sig. \\
\hline \multirow{2}{*}{ Problem solving skill } & $X 1$ & 4.07 & .66 & \multirow{2}{*}{-.25} & \multirow{2}{*}{.80} \\
\hline & $X 2$ & 4.10 & .55 & & \\
\hline \multirow[b]{2}{*}{$\begin{array}{l}\text { I usually try to find information as the first step in solving an } \\
\text { everyday problem }\end{array}$} & $\mathrm{X} 1$ & 3.98 & .81 & \multirow[b]{2}{*}{-.18} & \multirow[b]{2}{*}{.85} \\
\hline & $\mathrm{X} 2$ & 4.00 & .58 & & \\
\hline \multirow{2}{*}{$\begin{array}{l}\text { I usually try to find information as the first step in solving a nursing } \\
\text { problem }\end{array}$} & $\mathrm{X} 1$ & 4.18 & .74 & \multirow[b]{2}{*}{-.26} & \multirow{2}{*}{.79} \\
\hline & $\mathrm{X} 2$ & 4.21 & .68 & & \\
\hline \multirow[t]{2}{*}{ Confidence in ability } & $X 1$ & 3.96 & .59 & \multirow{2}{*}{$3.44 * *$} & \multirow{2}{*}{.00} \\
\hline & $X 2$ & 3.61 & .71 & & \\
\hline \multirow[b]{2}{*}{ I am able to find nursing information in the USQ library } & $\mathrm{X} 1$ & 4.04 & .85 & \multirow{2}{*}{$3.10^{* *}$} & \multirow[b]{2}{*}{.00} \\
\hline & $\mathrm{X} 2$ & 3.60 & .89 & & \\
\hline \multirow{2}{*}{$\begin{array}{l}\text { I am able to find nursing information in another library (hospital, } \\
\text { other university) }\end{array}$} & $\mathrm{X} 1$ & 3.57 & .89 & \multirow[t]{2}{*}{.94} & \multirow[t]{2}{*}{.35} \\
\hline & $\mathrm{X} 2$ & 3.44 & .87 & & \\
\hline \multirow[b]{2}{*}{$\begin{array}{l}\text { I am able to find nursing information by using the Library } \\
\text { databases }\end{array}$} & $\mathrm{X} 1$ & 4.13 & .76 & \multirow{2}{*}{$3.97 * *$} & \multirow[b]{2}{*}{.00} \\
\hline & $\mathrm{X} 2$ & 3.60 & 1.00 & & \\
\hline \multirow[b]{2}{*}{ I am able to find nursing books using the Library catalogue } & $\mathrm{X} 1$ & 3.97 & .86 & \multirow{2}{*}{$2.51 *$} & \multirow{2}{*}{.01} \\
\hline & $\mathrm{X} 2$ & 3.60 & 1.02 & & \\
\hline \multirow[b]{2}{*}{ I am able to find nursing journals using the Library catalogue } & $\mathrm{X} 1$ & 4.06 & .77 & \multirow{2}{*}{$3.26^{* *}$} & \multirow{2}{*}{.00} \\
\hline & $\mathrm{X} 2$ & 3.65 & .75 & & \\
\hline \multirow[b]{2}{*}{$\begin{array}{l}\text { I am able to find nursing information using computer search } \\
\text { engines }\end{array}$} & $\mathrm{X} 1$ & 4.07 & .80 & \multirow{2}{*}{$2.04 *$} & \multirow{2}{*}{.04} \\
\hline & $\mathrm{X} 2$ & 3.79 & .92 & & \\
\hline \multirow[t]{2}{*}{ Awareness } & $X 1$ & 4.44 & .54 & \multirow{2}{*}{1.26} & \multirow{2}{*}{.20} \\
\hline & $X 2$ & 4.33 & .53 & & \\
\hline I am aware that any first search results may not give me the & $\mathrm{X} 1$ & 4.37 & .63 & & \\
\hline information I require & $\mathrm{X} 2$ & 4.29 & .65 & .78 & .43 \\
\hline I am aware that the responsibility for self-learning rests with myself & $\mathrm{X} 1$ & 4.52 & .58 & & \\
\hline & $\mathrm{X} 2$ & 4.38 & .64 & 1.46 & .14 \\
\hline
\end{tabular}

* Significant at $\alpha=.05$ level of probability; ** Significant at $\alpha=.001$ level of probability

\section{G. Information Literacy of Nursing Students based on their country of origin}

Data illuminates marginally greater problem solving skills and overall higher confidence in information literacy ability of overseas students compared to students from Australia. The students from other countries show a significantly higher mean in everyday problem solving skills than the Australian students $(\mathrm{T}=-2.57, \alpha=.01)$. However, Australian students were more aware than overseas-born counterparts regarding information literacy, although this increase was not statistically significant.

\section{H. Information Literacy of Nursing Students based on their education}

In relation to overall problem solving skills, students who had completed "TAFE" had slightly higher mean scores than those who had nominated "Secondary school" as their highest education level. This was closely followed by those who listed "University and other" as their highest level of education. Overall the differences in information literacy confidence and awareness between "Secondary school", "TAFE" and "University and other" were minimal, although "University and other" scored marginally highest. However, there were no significant differences between students grouped according to educational 
background in their responses for problem solving skills, confidence and awareness in information access.

\section{Information Literacy of Nursing Students based on their prior learning}

Results show there were no significant differences in overall confidence in ability to access information except for the area regarding locating nursing books using the Library catalogue. The students who attended classes on finding and using information significantly differed from those who did not attend $(\mathrm{F}=2.870$, $\alpha=.05)$. A significant difference was also found in the area of awareness in relation to the students being responsible for self-learning $(F=3.703, \alpha=.02)$.

\section{J. Information Literacy of Nursing Students based on their at home access to computer}

Analysis of the results for students, based on their home availability of online computer access, indicated that while there were differences in the mean scale ratings for problem solving skills and confidence, none were statistically significant. There is a statistically significant difference overall in the information awareness area $(\mathrm{F}=5.363, \alpha=.001)$ and specifically in awareness that first search results may not provide the necessary information $(\mathrm{F}=6.103, \alpha=.001)$. In both cases Tukey test results uncovered that the difference was most pronounced between those that have online computer access available at home whenever they need it and those that had no home access at all.

\section{$K$. Overall comparison of semesters one, two and both (combined) based on demographic information}

The X1 campus students experienced an increase in overall confidence about their ability to access information between semester one and two. Conversely the X2 students experienced a small decrease in overall confidence. The X1 campus students demonstrated more confidence in information access skills than their X2 counterparts. Significant differences between campuses were found when both semesters were combined on all areas related to confidence $(\mathrm{T}=3.443$, $\alpha=.05$ ).

Analysis of data shows that overall problem solving skill was strongest in each semester in the 31 years and above age group and in both ( combined) semesters, a significant difference between this age group and the $16-18$ years group $(F=3.762, \alpha=.05)$. The $19-21$ years age group reported more skill in semester one than both the $16-18$ years and the $22-30$ years groups. However, all age groups showed a decrease in accessing information, as a problem solving skill, from semester one to semester two. Confidence in information seeking abilities increased in all age groups from semester one to semester two. This was the same for awareness about information except for the 19-21 years age group where they experienced a slight decrease in awareness.

The data in Table $\mathrm{V}$ indicates that there was an overall decrease in problem solving skills for both male and female students over the semesters. Confidence in ability to access information did experience some increase over the semesters but when combined, this was not significant. The area where most statistically significant differences were found was in awareness regarding information access. In each semester, as well as the combined semesters, female students were significantly more aware about information access and their own self-learning than the male students.

TABLE V. COMPARISON OF INFORMATION LITERACY OF THE STUDENTS BASED ON SEX

\begin{tabular}{|c|c|c|c|c|c|c|c|c|c|c|}
\hline \multirow[b]{2}{*}{ Area of literacy } & \multirow[b]{2}{*}{ Sex } & \multicolumn{3}{|c|}{ Semester 1} & \multicolumn{3}{|c|}{ Semester 2} & \multicolumn{3}{|c|}{ Combined } \\
\hline & & Mean & SD & $\mathrm{T}$ & Mean & $\mathrm{SD}$ & $\mathrm{T}$ & Mean & SD & $\mathrm{T}$ \\
\hline \multirow[t]{2}{*}{ Problem solving skill } & Male & 4.13 & .55 & \multirow{2}{*}{-.061} & 3.90 & .52 & \multirow{2}{*}{-.730} & 4.00 & .53 & \multirow[t]{2}{*}{-.750} \\
\hline & Female & 4.14 & .55 & & 4.04 & .73 & & 4.09 & .64 & \\
\hline \multirow[t]{2}{*}{ Confidence in ability } & Male & 3.77 & .62 & \multirow{2}{*}{.323} & 3.78 & .73 & \multirow{2}{*}{$-1.976^{*}$} & 3.77 & .68 & \multirow[t]{2}{*}{-.949} \\
\hline & Female & 3.71 & .60 & & 4.11 & .60 & & 3.90 & .63 & \\
\hline \multirow[t]{2}{*}{ Awareness } & Male & 4.22 & .51 & \multirow{2}{*}{-.962} & 4.12 & .61 & \multirow{2}{*}{$-2.834 *$} & 4.16 & .57 & \multirow[t]{2}{*}{$-2.633 * *$} \\
\hline & Female & 4.39 & .55 & & 4.52 & .49 & & 4.45 & .53 & \\
\hline
\end{tabular}

* Significant at $\alpha=.05$ level of probability; ** Significant at $\alpha=.001$ level of probability

While problem solving skills overall were shown to be stronger in overseas students, this was most statistically significant in semester one and combined semesters for everyday problems. Between semesters one and two confidence in information access ability increased for both Australian and overseas students. Confidence was generally stronger in students from other countries. Overall Australian students were generally slightly more aware about information access than students from other countries.

Increasing level of schooling displayed an adverse effect on using information as a problem solving skill in the first semester. This was levelled out when the semesters were combined, with "TAFE" reporting the strongest skill level. Predictably, confidence in information access abilities increased from semester one to semester two for every level of education, with those reporting "University and other" educational level as the most confident. These findings were replicated with the students' information literacy awareness.

Accessing information as a problem solving skill decreased as the semesters progressed whether or not students had attended classes on finding and using 
information. Those that were unsure of whether or not they had attended classes demonstrated no change. Confidence in ability to access information increased for both the groups who did and did not attend classes. Students who had not attended classes however, displayed more confidence in their ability than those who had. There was a statistically significant difference between these students and those that were unsure about their attendance $(\mathrm{F}=5.674, \alpha=.05)$. Overall awareness regarding information access increased from semester one to semester two.

Analysis of data shows that whether or not students have online computer access at home, it had no effect on their problem solving skills. When semesters one and two results were combined, students with readily available online computer access demonstrated higher mean scores than other groups. Confidence in ability to access information was also strongest with those that had ready access to an online computer. Overall confidence increased over the semesters. Significant differences were found in overall information awareness in semester one $(F=5.005, \alpha=.05$ and in the combined $(\mathrm{F}=5.363, \alpha=.05)$ results between those that did have readily available online computer access and those that had no online access at home.

\section{DISCUSSION}

Results showed minor decreases in problem solving skills between semesters one and two. This might not be a true reduction of actual skills because of the knowledge gained in semester two. Students may have become more aware of the set of skills necessary to use information literacy in their problem solving, resulting in a clarification of their perceptions. Based on analysis of the data, it was evident that using information as a first step in problem solving was a skill that increased with age. This is congruent with the notion that age impacts positively on problem solving skills [11]. Students who were from countries other than Australia displayed more strength in their problem solving skills. This could be related to several factors such as higher levels of education and attendance at information classes prior to enrolling in nursing. Students who had readily available online computer access at home had better problem-solving skills related to information literacy than those who did not.

Increases in students' confidence positively effects information seeking behaviours [10]. The confidence of the first year nursing students increased from semester one to semester two. This is to be expected given the students' increased exposure to learning experiences $[2,5,14]$ as well as embedded information literacy instruction in the curriculum. These increases were significant in all areas measuring information literacy confidence with the exception being confidence in the ability to find information in another library. This could be due to the students having little or no exposure to libraries other than their university library.
Further, no significant differences were found in most areas of information literacy according to whether or not students had attended classes on finding and using information prior to enrolling in the nursing program. Differences were found relating to students' confidence in their abilities to use the library catalogue. In this case, those students who were unsure about whether or not they had attended classes prior to enrolling at university were less confident in their ability compared to those students who had attended such classes [16]. This might be a factor which inhibited their ability to access information. This thought is reinforced by Croke [14], who states that as students' confidence increases, so does their propensity to engage in self-directed learning.

The confidence levels of students with readily available online computer access at home were small but persistently higher than those students without online access at home. This could be due to more exposure to online sources of information.

Analysis of data revealed that students' confidence in their information access abilities increased then plateaued at the 22-30 year age group and receded after this. The 31 years and above age group was least confident in finding information using library databases and computer search engines even though they had the highest level of at home online access in proportion than the other age groups[16]. Likewise Ip, et al. [11] stated that the acceptance of computer literacy is generally positive in the late teens to early 20 's age cohorts.

Those students who were unsure about whether or not they had attended pre university information literacy classes were less aware than those students who had attended classes. Contrast analysis generated significant results showing higher levels of awareness of information literacy in the group of students with readily available online computer access at home when compared to the students who had no such access. In part this may be because those students with convenient online access at their homes have more exposure to searching for information using computer search engines.

It was evident that male students were significantly less aware than female students regarding information access. As stated, the highest level of education attained prior to enrolling in the nursing program had no significant impact on information literacy.

\section{CONCLUSIONS}

As information literacy instruction is embedded into the first year nursing courses, students' confidence and awareness is positively affected by their increased exposure to information literacy in the nursing context. Attendance at information literacy classes improved students' confidence in their abilities to find relevant information and to engage in self-directed learning. Additionally, exposure to the various sources of 
information increased students' awareness of the scope of information. Given this evidence, the collaborative approach towards embedding information literacy instruction between the Department of Nursing and Midwifery, the Library and the Learning and Teaching Support Unit, and ICT, ought to be continued throughout the subsequent years of the nursing program. This will improve students' problem solving skills, confidence in their abilities and awareness of information literacy in nursing education.

\section{ACKNOWLEDGEMENT}

This project was funded by the Learning and Teaching Development Grants Scheme of the University.

\section{REFERENCE}

[1] S.K. Jacobs, P. Rosenfeld, J. Haber, Journal of Professional Nursing, Vol. 19 (2003) 320-328.

[2] E. Hartmann, Australian Academic \& Research Libraries, 32 (2001) 110-122.

[3] A. Shorten, C. Wallace, P.A. Crookes, International Nursing Review, 48 (2001) 86-92.

[4] A. Bundy, in: Australian and New Zealand Institute for Information Literacy (ANZIIL) and Council of Australian University Librarians (CAUL), Australian and New Zealand Institute for Information Literacy, Adelaide, 2004, pp. 52.

[5] R.G. Booth, International Journal of Nursing Education Scholarship, Vol. 3 (2006) 1-12.

[6] National Review of Nursing Education, in, Commonwealth of Australia, Canberra, 2002.

[7] M. Honey, N. North, C. Gunn, Health information \& libraries journal, Vol. 23 (2006) 102-109.

[8] K.S. Desjardins, C.S. Sheets, M. Jenkins, S. Bakken, International Journal of Medical Informatics, 74 (2005) 1012-1020.

[9] D.S. Pravikoff, A.B. Tanner, S.T. Pierce, American Journal of Nursing, 105 (2005) 40-51.

[10]A. Barnard, R. Nash, M. O'Brien, Journal of Nursing Education Vol. 44 (2005) 505-510.
[11]B. Ip, S. Jones, G. Jacobs, Innovations in education \& teaching international Vol. 44 (2007) 199-210.

[12] M.C. Wallace, A. Shorten, P.A. Crookes, Nurse Education Today, 20 (2000) 485-489.

[13] K. Flemming, K. Fenton, Making sense of research evidence to inform decision making., in: C. Thompson, D. Dowding (Eds.) Clinical decision making and judgement in nursing., Churchill Livingstone, Edinburgh, 2002, pp. 110-129.

[14]E. Croke, Contemporary Nurse, 17 (2004) 125-136.

[15]J. Tukey, Exploratory data analysis, AddisonWesley, Reading, Mass., 1977.

[16]C. Perrin, D. Hossain, K. Cumming, in: D. Orr, P.A. Danaher, G. Danaher, R.E. Harreveld (Eds.) 5th International Lifelong learning Conference Central Queensland University, Yeppon, Queensland, Australia, 2008, pp. 311-316.

Dr Delwar Hossain is Research Fellow, Centre for Rural and Remote Area Health, University of Southern Queensland, Toowoomba, Australia. Dr Hossain received his $\mathrm{PhD}$ in Extension Education from Michigan State University, USA and has more than 30 years of teaching, research and community development experience in USA, Bangladesh and Australia.

Associate Professor Cheryl Perrin is a registered nurse with an extensive background in nursing education. Cheryl teaches into the undergraduate and postgraduate nursing programs in the areas of leadership, management and health policy. Cheryl also holds the position of International Coordinator for the Faculty of Sciences at the University of Southern Queensland.

Ms Kaye Cumming is a Liaison Librarian (Sciences), Information Literacy and Reference Services, Library Services, Academic Services Division, University of Southern Queensland. 